\title{
実践研究
}

\section{自立活動における応重力姿勢の継続的経験が認知活動および 呼吸機能に及ぼす効果に関する実践的研究}

— 呼吸障害のある重度・重複障害児を対象として—

\begin{abstract}
小柳津 和 博*. 森 㠃 博 志**
本研究では、肢体不自由特別支援学校の重複障害学級に在籍する重度脳性まひ児 2 名の自 立活動の指導として動作法を適用した際の細かな発達的変化をもとに、自立活動の指導方法 として動作法の適用による教育的効果を検討することを目的とした。 1 年間の指導の結果、 対象児は応重力姿勢の獲得だけでなく、共同注意行動の発達、血中酸素飽和度の向上等がみ られた。重度・重複障害児への動作法を適用した指導は、自立活動の $6 つ$ つ分すべてに おいて効果がある点に教育的意義を提唱できることが具体的な実証デー夕をもとに示唆さ れた。

キー・ワード : 重度・重複障害児 自立活動 動作法
\end{abstract}

\section{I . 問題および目的}

近年、肢体不自由特別支援学校では各教科に替えて 自立活動を主とした教育課程で学習する重度・重複障 害児が増加し、有効な教育的支援の検討が望まれてい る。飯野（2009）は肢体不自由教育の専門性は自立活 動にあると述べており、肢体不自由特別支援学校の教 師にとつて自立活動の指導力の向上が必要不可欠であ る。しかし、有効な自立活動の指導方法について事例 をもとにした検討が十分になされているとはいえず、 今後も実践を通した指導方法の検討を進め、よりよい 教育的支援としての自立活動の学習を捉えなおしてい く必要があると考える。

森㠃（2003）は、重度・重複障害の脳性まひ児に週 1 回の夕テ系姿勢獲得を目指した動作訓練を行った事 例における良好な教育的変化を、文部省（1999）の自 立活動の 5 つの区分に照らし合わせて報告している。 現行学習指導要領の視点では、本吉 (2014) が心理り ハビリテイション 1 週間キャンプにおいて重度・重複 障害者に対して動作法を適用した際の効果を自立活動 の 6 区分（「健康の保持」「心理的な安定」「人間関係 の形成」「環境の把握」「身体の動き」「コミュニケー

* 豊田市立豊田特別支援学校

** 愛知教育大学
ション」)から検討している。森㠃 (2003)、本吉 (2014) では、動作法は自立活動の区分すべてにおいて良好な 影響を及ぼすことを述べているものの、訓練会等にお ける事例によるものであるため、学校現場での指導に おける効果の検討は十分に行われていないことを課題 としている。

肢体不自由児は、文字通り自立活動の 6 区分におけ る「身体の動き」に課題を有しているものが多い。肢 体不自由を主とする重度・重複障害児にとつて、「身 体の動き」を介した関わりが、自立活動の目標である 「学習上又は生活上の困難を主体的に改善・克服する」 (文部科学省, 2009a, 2009b) ための学習として最も重 要であると筆者は考える。ただし、森㠃（2003）は、 一般的に肢体不自由児の自立活動の指導が「身体の動 き」だけに注目されがちで、子どもと体を直接介した 関わりそのものが、いかにその子らの運動面以外の発 達の基盤となっているかについては認識がそしいと警 鐘を鳴らしており、運動発達とその他の発達との関連 について検討を進める必要がある。

肢体不自由児の姿勢・運動面の発達と認知発達に関 する研究を概観してみると、成瀬（1995）が、夕テ系 姿勢は自分の体軸を原点にした上下、遠近、左右とい う座標軸が形成され、その座標軸の枠を基準にして外 界環境を認知し、物理的世界を識別できるようになる 
ための基軸となるものであり、単に姿勢がとれるよ うになることだけを意味しないと述べている。川間 （1999）は座位姿勢などの重力に対応した姿勢を聴覚 や視覚を十分に働かせる姿勢として推奨しており、そ の理由として (1) 頭部を自由に動かせるようにほぼ垂 直の位置に保つことが必要なこと、(2) 注意や覚醒水 準を高めることができること、(3)特に視覚からの刺 激は志向性をもって見ることがなければ有効な情報と して取り入れることが困難であること、の 3 点をあげ ている。また森㠃（2003）が述べるように、座位姿勢 を獲得することは、手がフリーな状態になり、手を使 い始めるための足場となることで、対象操作による認 知発達を促すことができることも利点であるといえ る。以上の点から、姿勢と認知の関連は密接であるよ うに、自立活動の学習においても「身体の動き」と 「他の 5 区分」は密接な関連があるのではなかろうか。

重度・重複障害児は、運動面の困難をはじめとし、 対人認知などの認知面の困難、呼吸や摂食などの健康 面の困難などさまざまな学習上・生活上の困難に直面 している。それらの困難を主体的に改善・克服する学 習として、いま一度、学校現場発信による自立活動の 学習の再構築を行う必要があろう。そこで、本研究で は、学校現場において重度・重複障害児に対する自立 活動の学習として、応重力姿勢の継続的経験を中心と する動作法を適用した指導を展開した際の運動面、認 知面、健康面などの多面的な学習成果の関連を詳細に 検討することとした。その中で実証に基づいた検討を 進めるため、認知面については「共同注意行動」を、 健康面については「血中酸素飽和度（以下、 $\mathrm{SpO}_{2}$ )」 を取り上げた。これらの多面的デー夕をもとに、動作 法を適用した自立活動の指導の教育的意義を 6 つの区 分を視点にして検証することを目的とした。

\section{II. 方 法}

\section{1. 対象児}

（1）A 児：肢体不自由特別支援学校小学部 1 年 生の女児。重複障害学級に在籍し、自立活動を主とし た教育課程で学習している。主障害は脳性まひで、知 的障害を併せ有している。身体障害者手帳は 1 種 1 級、 療育手帳は $\mathrm{A}$ 。呼吸障害により気管切開をしており、 日常的に医療的ケア (気管切開部の管理、痰の吸引) を受けている。

指導開始当初の実態として、運動面では体全体の緊 張が強く、座位保持は難しい。仰臥位から右下側臥位 までは寝返りができる。認知面では、アイコンタクト
は可能で、指さし理解（視野内）は不可。健康面では、 自力排痰が難しく、常に喘鳴を伴った呼吸をしてい る。個別の指導計画における自立活動（時間の指導） の目標は以下の 3 点である。(1) 少しの時間一人であぐ ら座位を保持できる。(2)体の過度な緊張を緩め、大き な呼吸ができる。(3)教師が伝える動きに応じようと することができる。

(2) B 児：肢体不自由特別支援学校小学部 2 年 生の女児。重複障害学級に在籍し、自立活動を主とし た教育課程で学習している。主障害は脳性まひで、知 的障害を併せ有している。身体障害者手帳は 1 種 1 級、 療育手帳は $\mathrm{A}$ 。

指導開始当初の実態として、運動面では、両手をつ いて支えにしたあぐら座位を保持できる。補助されて 立位をとると、上体を起こすことが難しい。左右への 寝返りで短い距離を移動することができる。認知面で は、排尿を伝えるサインができ、簡単な動作模倣がで きつつあった。健康面では、呼吸状態は一般的だが $\mathrm{SpO}_{2}$ は低く、平均值は $94 \%$ 台。個別の指導計画にお ける自立活動（時間の指導）の目標は以下の 3 点であ る。(1)安定した座位やつかまり立ち姿勢の保持がで きる。(2)寝返りや腹ばいで短い距離を移動すること ができる。(3)教師が伝える動きの指示に応じて体を 動かすことができる。

\section{2. 期 間}

$\mathrm{A}$ 児: $20 \mathrm{XY}$ 年 4 月 $20 \mathrm{XY}+1$ 年 3 月（119 時間）

$\mathrm{B}$ 児: $20 \mathrm{XZ}$ 年 4 月 $20 \mathrm{XZ}+1$ 年 3 月（128 時間）

\section{3. 手続き}

筆者が担当する週 4 時間の「自立活動（時間の指 導)」において、動作法を適用した指導として、応重力 姿勢（座位、立位など重力に応じて身を起こす姿勢） の獲得を中心とし、主体的な動きを引き出す指導を展 開する。指導時間内におもな動作課題（姿勢、動き） のテストを 5 分程度実施し、運動面の変化について記 録する。また、2週間に1度テスト場面を撮影し、映像 をもとに他の教師と対象児の変化について記録する。

認知面の変化については、森㠃 $(2002,2004)$ の先 行研究をもとに共同注意行動に着目する。アイコンタ クトから指さし産出（叙述）までの 10 項目の共同注 意行動について、自立活動（時間の指導）以外の授 業場面で各項目 1 日 1 回のテスト（例：「指さし理解 (視野外)」は、対象児の視野外にある教材を筆者が指 さして、教材のほうへ注意を向けたかどうかを確認す る）を実施し、可・否として記録する。対象児の共同 注意行動におけるテストの結果として、各項目で月ご 
との正答率（正答率＝各項目における 1 か月間の正答 合計数 /月の授業日数）を算出する。

運動面、認知面については、「自立活動（時間の 指導)」以外の学習場面における変化についても記録 する。

健康面を評価する指標として、 $\mathrm{SpO}_{2}$ を月〜金曜日 までの授業日、登校直後（午前 9 時 00 分前後）に座 位保持装置に座った姿勢にてパルスオキシメーター （コニカミノルタセンシング社製）を使用して測定し、 結果を記録する。

\section{III. 結果および考察}

1 年間の指導による結果を、運動面、認知面、健康 面、その他の変化に分け、おもだった変化について A 児は Table 1、B 児は Table 2 にまとめた。Table 1、 Table 2 の結果をもとに、対象児の変化や発達に至つ た背景について考察する。

\section{1. 運動面について}

Table 1 より、A 児は片側のみ寝返りは獲得してい た。4月より動作法を適用した自立活動の指導（座位、 立位など応重力姿勢獲得を中心とし、主体的な動きを 引き出すことを目的とした指導) を開始すると、5 月 頃よりあぐら座位が 3 秒程度保持できるようになっ た。相前後して 6 月頃より左右両方への寝返りが可能 になり、おもちゃに手を伸ばすなどのリーチングがみ ら机、外界へ主体的に働きかけようとする姿へとつな がつた。

Table 2 より、B 児は指導開始時に寝返り、両手を支 えとして床に着けてのあぐら座位保持は獲得してい た。4月より動作法を適用した自立活動の指導を開始 した後、B児においては11月頃に両手の支えに頼らな い座位保持が可能となった。相前後して 9 月頃からつ かまり立ちがみられた。7 月頃に腹ばいでの移動を獲 得した。これらにみられる両事例の運動発達の様相 は、一般の乳幼児にみられる発達の流れ（座位保持か ら移動運動、その後の立位保持につながる）と共通す るものと考元る。その発達を色濃く引き出した要因 は、応重力姿勢の継続的経験が基盤となっているもの と考える。

応重力姿勢として A 児が座位保持を獲得した時期、 B 児が手の支えなしの座位保持を獲得した時期に注目 したい。A 児は、7 月頃より立ち直り反応がみられる ようになることで座位保持時間が延びていった。B 児 においては、12 月頃に座位で姿勢の傾きを修正でき るようになり、手の支えなしで背中を伸ばした座位保
持が可能になった。これらの結果から、一般の乳幼児 同様、立ち直り反応にみられる腰を中心とした微細な バランス取りをする力が、重度・重複障害児において も安定した座位保持を引き出すうえで欠かせない要因 であることが示唆された。動作法を適用した自立活動 の指導は、対象者の腰の動きに着目しながら応重力姿 勢の獲得を促すことができ、重度・重複障害児に一般 の乳幼児に近い運動発達を促すことができる点におい て高い有効性があると考える。

本研究における運動面の発達は、自立活動の 6 つの 区分による視点からみると「身体の動き」に当たる。 肢体不自由児の障害による学習上または生活上の困難 は「身体の動き」が主たる要因となることはいうまで もない。「身体の動き」における運動発達こそが肢体 不自由児の生きる力を育み、その後の生活を支える 基盤となるものと考える。本研究では、両事例で座 位、立位等の応重力姿勢の保持を可能にした。また、 寝返りや腹ばいを獲得するなどの移動運動の発達も促 した。

本研究における運動面の発達から、動作法を適用し た自立活動の指導は「身体の動き」における站らいを 十分に満たすことができる有効な手立てであることが 示唆された。

\section{2. 認知面について}

前述の通り、共同注意行動の正答率を月ごとに算出 し、変化の様子について、A 児を Fig. 1 1 B B 児を Fig. 2 にまとめた。Fig. 1、Fig. 2 の凡例は先行研究（森㠃, 2003; 大神, 2002; 徳永, 2009）を参考に、一般の乳幼児 の発達過程順に上から並べた。

Fig. 1より、A 児は 5、6 月頃に「指さし理解（視野 内）」、動作模倣（意図的）」指さし理解（視野外）」 「提示・手渡し (応答)」などの共同注意行動の正答率 が高まり出した。A児の 5、6月の運動面の変化をみる と、座位保持が始まり、左右両方へ寝返りを獲得し、 おもちゃ等へのリーチングを獲得した時期と重なる。 運動面で複数の発達がみられる時期に重なり、認知面 の発達がつながっている結果から、運動発達を促すた めの動作法を適用した自立活動の指導が、共同注意行 動の発達を促すことに結びついたと推察される。運動 面の発達が共同注意行動の発達につながつたと考える 要因として、(1) 座位等の応重力姿勢獲得を目指す指 導を展開した結果、体を起こして上体を保持する力が 養われ、視覚を通して外界情報を正しく捉えるための 身体基盤が整ったこと、(2) 寝返り動作の獲得を目指 した指導を展開した結果、移動運動としての寝返り動 


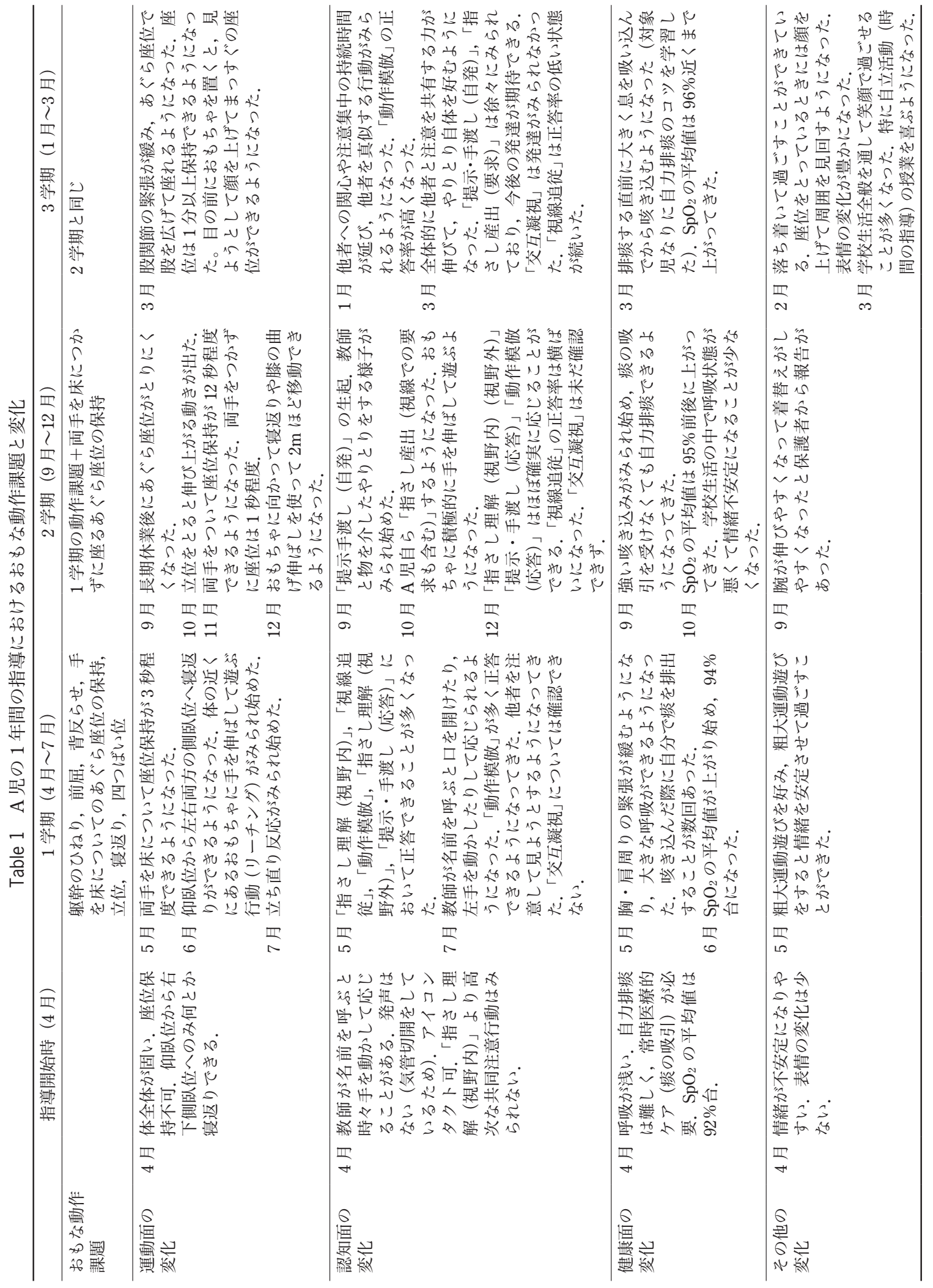




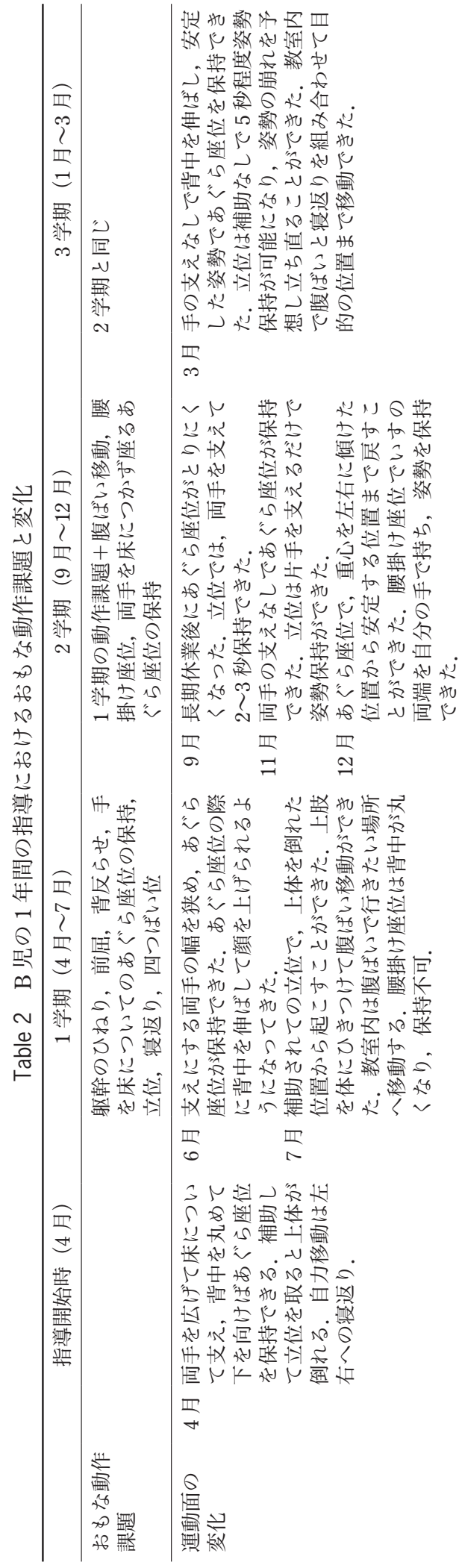

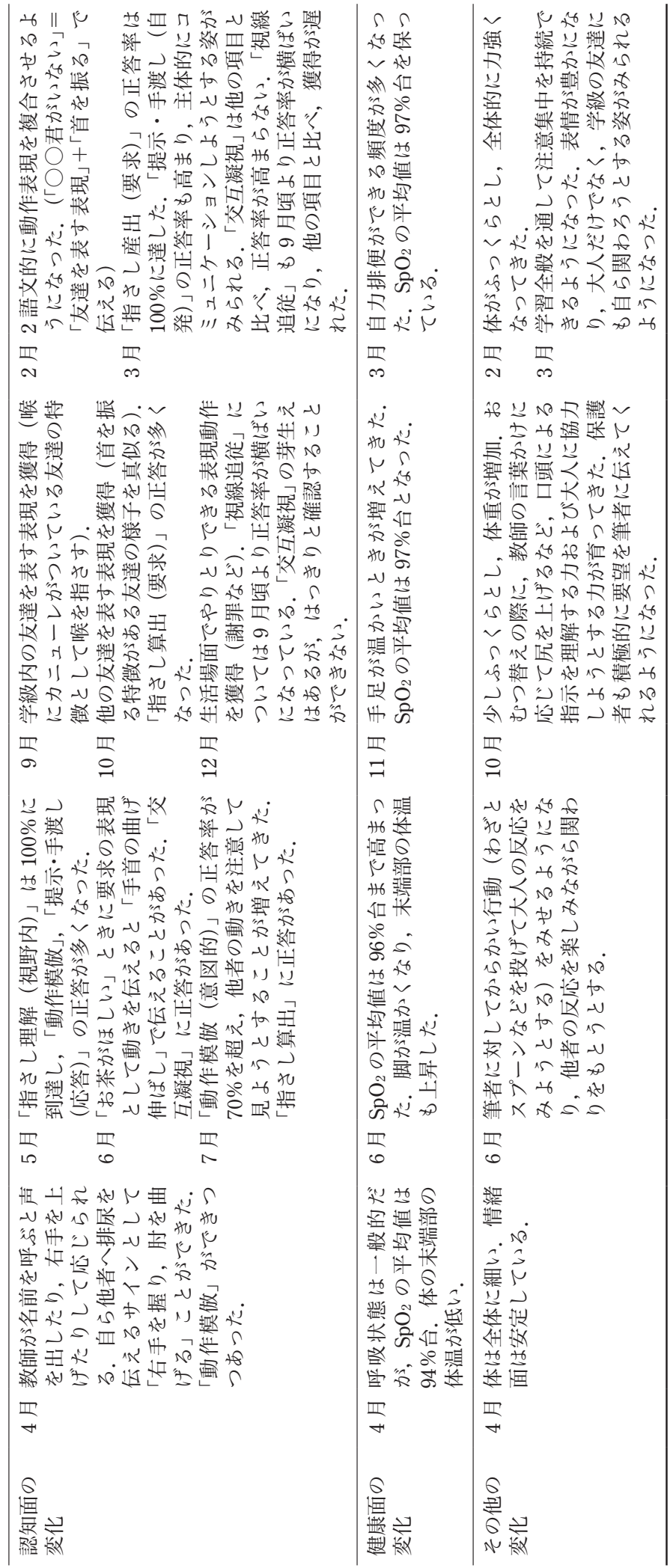


作の獲得に伴い、主体的な姿勢の変換により、注視点 の変化が頻繁になり、さまざまな角度から外界の情報 を捉える機会が広がったこと、(3) 対象物へのリーチ ングを獲得したことで、対象を操作し、特性を認知す る機会が増加し、物を介して他者と関わるための基礎 的な力が高まったこと、(4)教師と体の動きを通した 交流を継続した結果、筆者が伝える動きを認識し、対 象児なりの動作で答えるやりとり（相互交涉）が成立 し始め、動作を介したコミュニケーションが対人認知 を育むことに繋がったこと、これらの 4 点が大きく関 与しているものと考元られる。

Fig. 2 より、B 児の共同注意行動の発達において注 目すべきは、正答率が $40 \%$ 台を推移していた「指さし
理解 (視野外)」が 1 月以降に $70 \%$ 台に高まった点で ある。「指さし理解（視野外）」の正答率が高くなつた 1 月は、両手の支えに頼らずに座位保持が可能になっ た後の時期である。大神（2002）は、「指さし理解（視 野外)」は一般の乳幼児において、(1) 三次元空間の中 に体を定位させる能力、(2)首と躯幹の回転などの身 体操作能力、(3) 自己と物の配置に関する空間理解、の 3 つの力が発達してきたことによって獲得されると述 べている。B 児においては、以下の 3 点の発達が複合 的に重なりあって発達した時期に「指さし理解（視野 外)」の正答率が高まっている。(1) 安定した座位の保 持とつかまり立ちが可能になり、三次元空間にて自己 を定位する能力が高まったこと、(2) 体幹部の回転運

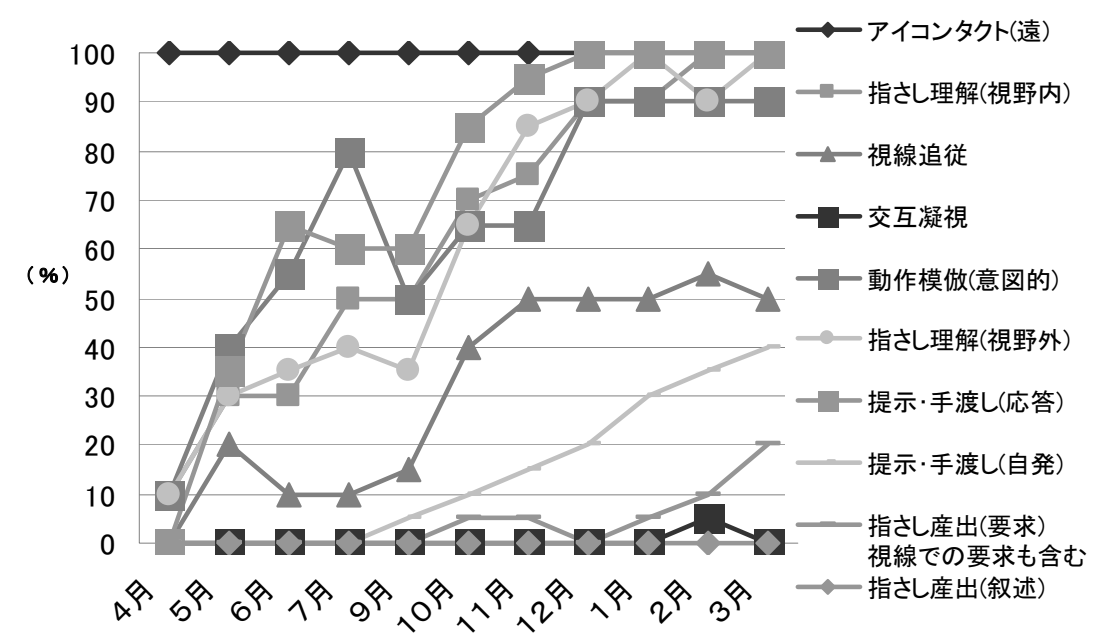

Fig. 1 A 児の共同注意行動の変化

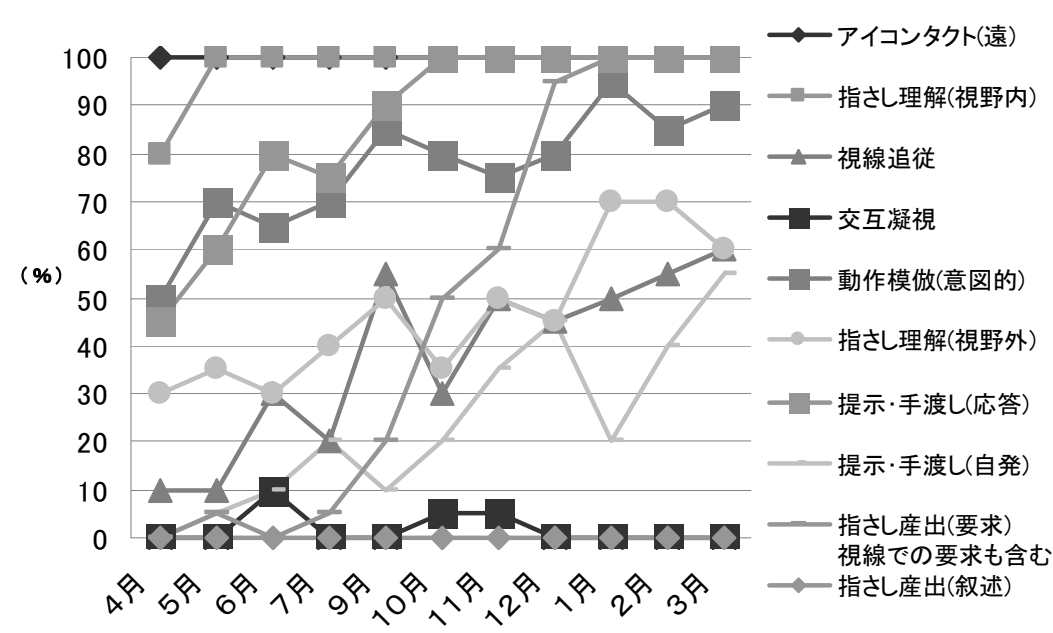

Fig. 2 B 児の共同注意行動の変化 
動を阻む過剩な筋緊張を緩める課題に取り組み、首と 躯幹の身体操作能力が高まったこと、(3)志向性を もつて物や他者の動きを見たり、腹ばいでの移動が可 能になったりしたことで、自己と物との認識および配 置に関する理解が高まったこと。この 3 つの力の発達 と「指さし理解 (視野外)」獲得の発達との重なりは、 大神 (2002) が述べる一般の乳幼児の発達過程と一致 している。このことから、大神（2002）のいう「指さ し理解 (視野外)」獲得に必要な 3 つの力の発達を促 す指導を展開することで、重度・重複障害児において 共同注意行動の発達を高められる可能性があると推察 される。

次に、6 月以降に「提示・手渡し (応答)」の正答率 が $80 \%$ まで高まり、その後も高い正答率で推移して いる点に着目したい。大神（2002）は、「提示・手渡 し (応答)」は「指さし理解」と「指さし算出」の間 に位置し、両者の発達的連鎖を橋渡しする役割となる と述べている。つまり、一般の乳幼児に打ける発達順 に並べると、「指さし理解（視野内・視野外）」 $\rightarrow 「$ 提 示・手渡し (応答) 」 $\rightarrow$ 「指さし算出」となる。B 児の場 合、「提示・手渡し (応答)」の発達が「指さし理解 (視野内) 」よりも後であり、「指さし算出 (要求)」よ りも前であることから、一般の乳幼児と同じ発達過程 であるといえる。しかし、「指さし理解（視野外）」の 獲得は、「提示・手渡し (応答)」や「指さし産出」よ りも遅れた。このことは一般の乳幼児の発達過程と重 ならない。B 児は「指さし理解 (視野内) 」 $\rightarrow$ 「提示・手 渡し (応答) 」 $\rightarrow$ 「指さし算出」 $\rightarrow$ 「指さし理解 (視野外)」 と発達したのである。一般の乳幼児における発達と相 違があるこの現象は、B 児の肢体不自由という障害が 関与したことによるものと推察される。B 児は肢体不 自由という障害から、体を意図通りに操作することに 困難があり、「指さし理解 (視野外)」の発達に欠かせ ない 3 つの力 (大神, 2002) のうち (1) 三次元での身体 定位能力、(2)首と躯幹の回転などの身体操作能力の 2つについては発達しにくい状況にある。このことが、 「提示・手渡し (応答)」や「指さし産出」よりも「指 さし理解 (視野外)」の正答率が高まりにくかった原 因であると考えられる。

そのほかに、両事例で注目すべき共通点が 2 つあ る。1点目は、両事例において「交互凝視」の正答率 が 0〜 5\%とほとんど高まりがなかったことである。2 点目は、一般の乳幼児では早い段階で獲得するはずの 「視線追従」の正答率が、「動作模倣 (意図的)」や「提 示・手渡し (応答)」などの比較的高次な共同注意行
動よりも高まらず、50\%程度でとどまっていた点であ る。「交互凝視」「視線追従」は、視線を切り替える際 に対象となる人と、その視線の先との間に距離が生じ やすい。そのため、他の共同注意行動に比べ、「交互 凝視」「視線追従」を獲得する際には離れた位置に正 しく視線を動かすことを支えるために、体を起こした 際の首の定位と自在なコントロールが身体基盤として 必要となるのではないかと考えられる。A 児は体を起 こした姿勢の中で常時首を定位し続けることは難し く、B 児も首のコントロールが自在であるとはいいが たい。それらの影響が「交互凝視」「視線追従」の獲 得を妨げていると考えられる。重度・重複障害児の認 知面において「交互凝視」「視線追従」を高めるため には、運動面において首の定位とコントロールを高め ることが必要であるとともに、「交互凝視」「視線追 従」の獲得の遅れは肢体不自由特有の発達の様相であ ると推察できる。以上の結果から、肢体不自由特有の 発達の偏りの可能性はあるものの、認知面の発達を下 支えする運動発達を促すことができる動作法を適用し た自立活動の指導は、重度・重複障害児の認知面を高 めることに有効であると考えられる。

本研究における認知面の発達は、自立活動の 6 つ の区分による視点からみると、「人間関係の形成」「環 境の把握」「コミュニケーション」に当たると考えら れる。

「人間関係の形成」は、人との関わりの基礎となり、 社会生活を送る上で必要不可欠である。本研究では、 両事例とも共同注意行動が発達し、他者への主体的な 関わりがみられた。この発達の背景に、動作法を適用 した自立活動の指導として、以下の 2 点が関与してい るものと考えられる。1点目は、教師と一対一の体の 動きを介したやりとりによって、他者から動きによる 働きかけを受けた自己の動きを認識し始め、自と他の 理解が芽生えたことである。その過程において、自己 へ注意が向きやすい未発達な世界から、他者に注意を 向けられる分化した世界に突入したものと考元られ る。それが、他者へ主体的に関わりを求める姿へとつ ながったのではないか。2 点目は、成功体験の積み重 ねが主体性の発達に関与したと考元られる点である。 体の動きを介したやりとりは、小さな変化から子ども と教師が共に「できた（成功した）」という成功体験 を感じやすい。子どもが教師と同時に感じる成功体験 の繰り返しが主体性を引き出し、その主体性が他者と の関わりにも表的たものと考えられる。

「環境の把握」の力を高めることは、周囲の状況を 
捉える力となり、生活力の向上につながる。本研究で は、事例において主体的に他者とやりとりをしたり、 リーチングを通じて対象物に主体的に関わったりする など、外界への興味が拡大した。この変化において、 動作法を適用した自立活動の指導が関与した点は、応 重力姿勢の獲得であると考えられる。両事例では応重 力姿勢の獲得により、成瀬（1995）が述べるように、 自分の体軸をもとに形成された座標軸を基準にして、 周囲の物を把握するようになつたことが外界への興味 拡大の背景になったと考えられる。さらには、リーチ ングの発達により、自らの身体操作を通じて自己と物 との距離を把握できるようになった。また、寝返りや 腹ばい等の移動運動が発達したことで、物との距離を はじめとする自己と物との関係把握につながり、対物 認知等を主とする外界認知や遠近感の理解にもつな がったと考朰れる。

「コミュニケーション」は、障害のある子どもたち のみならず、人として日常生活を豊かにする上で最も 重要な力のひとつであると考えられる。本研究では、 コミュニケーションの発達を両事例の共同注意行動の 発達の様相から捉え、詳細に検討してきた。本研究に おいて、動作法を適用した自立活動の指導が、重度・ 重複障害児の共同注意行動の発達を促すことにつな がった点として、以下の7点が考えられる。(1) 三次元 空間の中に自分の体を定位させる力が高まったこと。 (2) 首や体幹を回転させる身体操作能力が高まったこ と。(3)自己と物の配置に関する空間理解が発達した こと。(4)座位獲得過程において、(1)〜(3)をもとに自
分の体軸を原点にした座標軸が形成され、外界認知が 発達したこと。(5) 移動運動が可能になり、外界への働 きかけ行動が活発になったこと。(6)体の動きを通し た密なやりとりにより、互いの動きに注意を向け、注 意を共有する力が培われたこと。(7)手指動作と対象 操作が発達したことで、物を介した 3 項関係の中での やりとりが広がつたこと。これらの総合的な発達によ り共同注意行動の獲得につながつたと考えられる。動 作法は身体相互交渉ともいえ、動作法を適用した自立 活動の指導は、動作による重度・重複障害児とのコ ミュニケーションを可能にする。自立活動の学習によ り培った力が生活場面に般化され、共同注意行動の発 達につながつたと考えられる。

本研究における認知面の発達から、動作法を適用し た自立活動の指導は、「人間関係の形成」「環境の把 握」「コミュニケーション」におけるねらいを十分に 満たすことができる有効な手立てであることが示唆さ れた。

\section{3. 健康面について}

両事例の $\mathrm{SpO}_{2}$ の平均值を月ごとに算出し、変化の 様子を Fig. 3 に示した。

パルスオキシメーターによる $\mathrm{SpO}_{2}$ の数值の一般的 な読み方は、コニカミノルタセンシング（2009）によ ると、「89\%以下を（急性）呼吸不全、90\%〜95\%を 準呼吸不全、96\%以上を一般的に健康な状態」とされ ている。

A 児は呼吸障害があることから気管切開をしてお り、4 月当初の $\mathrm{SpO}_{2}$ の平均值は $92 \%$ 台であった。し

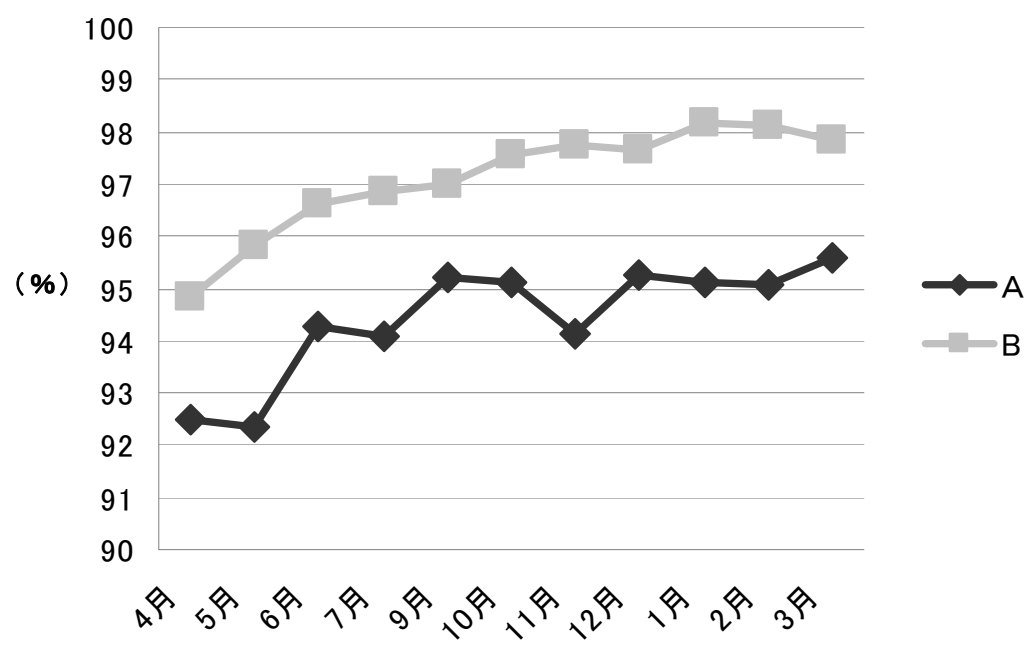

Fig. $3 \mathrm{SpO}_{2}$ の月平均の変化 
かし、6月には上昇し始め、9月には $95 \%$ を超えた。

B 児の場合、 $\mathrm{SpO}_{2}$ の平均值は 4 月当初で $94 \%$ 台で あった。呼吸障害はないが $\mathrm{SpO}_{2}$ の数值からみると健 康な状態とはいえなかった。しかし B 児においても 徐々に上昇がみられ、6月には $96 \%$ 台まで高まった。

動作法を適用した自立活動の指導が $\mathrm{SpO}_{2}$ の上昇に つながると考えた背景として、以下の 2 点があげられ る。1 点目は、過剩な筋緊張を緩める学習が、 $\mathrm{SpO}_{2}$ 平 均值上昇にみら机る呼吸状態の改善に有効であると考 えられる点である。 $\mathrm{SpO}_{2}$ の平均值が上昇し始めた 6 月 頃は、過剩な筋緊張が緩んできた時期と一致する。両 事例において動作法を適用した自立活動の学習の成果 として、胸・肩・背中周りの筋緊張が緩んだ。併せ て、上体が起きた姿勢へと変化した。これらにより、 肺を大きく膨らませて呼吸活動を円滑に行うための身 体基盤が整ったことが、 $\mathrm{SpO}_{2}$ の平均值上昇に好影響 を与えたと考える。2 点目は応重力姿勢により適切な 緊張を引き出す学習が、 $\mathrm{SpO}_{2}$ 上昇にみられる呼吸状 態の改善に有効であると考元る点である。A児の $\mathrm{SpO}_{2}$ の平均值が高まった $6 、 7$ 月頃の運動面の変化をみて みると、応重力姿勢として座位保持が可能になりだし た時期と一致する。 $\mathrm{B}$ 児において、 $\mathrm{SpO}_{2}$ 平均值の上昇 がみられた 9、10月は、運動面において両手の支えに 頼らない座位保持が安定し、つかまり立ちの保持が可 能になった時期と一致する。座位や立位をとること自 体が対象児にとって全身運動となり、第二の心臓とい われる脚を積極的に使うことで、血流量の増大といっ た自律神経の活性化も背景として生じさせ、 $\mathrm{SpO}_{2}$ 平 均值上昇に好影響を与えたと考える。

本研究における健康面の発達は、自立活動の 6 つの 区分による視点からみると「健康の保持」に当たる。

「健康の保持」は重度・重複障害児の学習内容とし て最も重要な位置を占める。本研究では両事例とも、 動作法を適用した自立活動の学習を継続する中で $\mathrm{SpO}_{2}$ の平均值が高まった。この健康面における良好な変化 を引き起こした要因は、(1)動作法を適用した指導に より体の過剩な筋緊張を緩め、適切な緊張状態を引き 出すことができたこと、(2)応重力姿勢を継続的に経 験すること自体が適切な負荷の運動となったことであ ると考えられる。

本研究における呼吸状態の改善を主とする健康面の 変化から、動作法を適用した自立活動の指導は「健康 の保持」におけるねらいを十分に満たすことができる 有効な手立てであることが示唆された。

\section{4. その他の変化について}

Table 1 より、A 児は 1 年間の指導の結果、学校生活 の中で涙を流して不安を訴えることが減少し、安定し た情緒を保持できるようになった。これは、動作法を 適用した自立活動の学習として、指導者と一対一の体 の動きを介したやりとり自体を楽しめるようになった ことで、他者理解が進み、心理的に安定を図ることが できたためと考える。両事例とも、動作法を適用した 自立活動の学習を行う以前は、徳永 (2004) の述べる 「自己と他者、対象物の区別のない混とんとした世界」 にあり、他者理解として自己と他者の区別がはっきり としない状態にあったのではないかと考えられる。自 己と他者の区別の曖昧さが情緒の安定感を摇るがす負 因子になっていたのではなからうか。しかし、教師と 一対一の体の動きを介したやりとりを重㸚ることで、 自己と他者の間に意図が存在し、自己である私と他者 である教師が別の意思ある存在と気付き始めたと考元 られる。対象児は体の動きを介したやりとりの中で、 教師が伝える動きの指示に応じて体を動かすことがで きるようになった。それにより、他者理解や他者意図 理解が進み、徳永 (2004) の述べる自他未分化な「混 とんとした世界」から、「自己と他者のゆるやかな分 化」「刺激的な他者（2 項関係の形成）の世界」「自分 と自体、物の操作の世界」に入り始め、外界のさまざ まな事象が把握できる状態へと発達した。この外界認 知の発達が、対象児の不安減少および情緒の安定につ ながったと考える。

本研究における「その他の変化」にみられる情緒の 安定は、自立活動の $6 つ$ つ分による視点からみると 「心理的な安定」に当たる。

「心理的な安定」を図り、安定した状態を保つ力を 育んでいくことは、障害のある子ども本人だけでな く、障害児を取り巻く周囲の人にとっても高いニーズ があると考えられる。本研究では、特に A 児において 情緒の安定が顕著にみられた。事例における情緒の安 定には、以下の 2 点が関与したものと考えられる。(1) 動作法を適用した自立活動の指導を展開することで、 他者認知および外界認知の高まりを促し、不安定にな りやすい混とんとした世界を軽減することができたこ と、(2) 教師と動作を通じてやりとりする中で、教師の 求める動きに応じて体を動かし、自体に注意を向ける 技能が高まったこと。さらには、教師の求める動きに 応じる成功体験を繰り返す中で、他者とつながったこ とを実感でき、「他者とつながりたい」という主体性 が高まったことも、情緒の安定につながったものと考 


\section{えられる。}

本研究における情緒の安定に関する変化から、動作 法を適用した自立活動の指導は、「心理的な安定」に おけるねらいを十分に満たすことができる有効な手立 てであることが示唆された。

\section{IV. 総合考察}

本研究では、事例において応重力姿勢の継続的経験 を中心におき、移動運動と対象操作を相互に関連付け ながら指導を行った。これにより座位や立位の保持と いつた応重力姿勢の獲得、寝返りや腹ばい等の移動運 動の獲得、リーチングによるおもちゃ遊び等で対象操 作の向上がみられた。この背景には、教師と体の動き を介した密なやりとりが存在するものと考える。これ は自立活動の $6 つ$ つ分における「身体の動き」であ る。この「身体の動き」を中心とした相互交渉が基盤 となることで、人との結びつきをもつための基本的な 力を培うこととなり、「人間関係の形成」において発 達的な効果がみられたと考えられる。さらには「人間 関係の形成」を足がかりに、他者と体の動きを介して のやりとりが「コミュニケーション」の力を育むこと になった。そして、教師とつながる感じや意図通りに 動作ができる感じをもつことで、「心理的な安定」の 力を培った。同時に体を積極的に動かしたことで自分 の体をより生活しやすい状態に整えることができ、 「健康の保持」にも効果がみら机た。また、重力に応 じて体を起こし、移動運動およびリーチングを獲得し たこと、周囲の状況を把握する力が高まったことで、 「環境の把握」にも効果があったと考えられる。

自立活動（時間の指導）において、「身体の動き」 に関する力を育むために動作法を適用し、応重力姿勢 獲得を軸とした指導を展開したことで、その他の 5 つ の区分（「健康の保持」「心理的な安定」「人間関係の 形成」「環境の把握」「コミュニケーション」）におい て良好な発達的変化がみられた。さらに、それら5つ の区分は相互に関連しあうとともに、「身体の動き」 へのフィードバックも行いながら総合的に 6 つの区分 における発達的関係を強固にしたものと考える。

このことから、重度・重複障害児にとつて動作法を 適用した自立活動の指導は、自立活動の 6 つの区分す べてに効果があり、学習上・生活上の困難を主体的に 改善・克服する目標を十分に満たすことができる点に 大きな教育的意義があるといえる。

\section{V. 今後の課題}

本研究は、脳性まひ児を対象とし、限られた障害種 をもとにした検討である。今後は、他の障害種におい ても同様の結果が得られるか否かを検討する必要があ る。特に、重度・重複障害児において「視線追従」お よび「交互凝視」等の視線を中心とした共同注意行動 の獲得に遅れが生じる可能性があると推察した点につ いて、他の事例をもとに詳細に検討する必要がある。 また、本論を通じて述べてきた対象児の発達は、いう までもなく動作法を適用した自立活動（時間の指導） の指導のみによる効果ではない。しかし、逆に動作法 を適用した指導を展開せずに過ごした場合、これだけ の発達的変化がみられるとも考えにくい。今後は一つ 一つの変化において、動作法を適用した指導によるも のか、それとも他の指導によるものなのか、検討を深 める必要がある。本研究を通して直面した課題に今後 も取り組んでいくことで、より質の高い重度・重複障 害児への教育的支援のあり方を探っていきたい。

\section{謝 辞}

筆者との学習を通じて大きく成長し、たくさんの感 動を与えてくれた子どもたち、本研究の協力・公表に 関して快くご理解いただいた保護者様に心より感謝申 し上げます。記して謝意を表します。

\section{文 献}

飯野順子 (2009) 肢体不自由教育の専門性を巡って. 肢体不自由教育, 188, 6-11.

川間健之介（1999）ポジショニング. 肢体不自由教育, $141,45-53$.

コニカミノルタセンシング (2009) $\mathrm{SpO}_{2}$ を読む話一パ ルスオキシメーターの基礎一.コニカミノルタセン シング株式会社.

文部科学省 (2009a) 特別支援学校学習指導要領.

文部科学省 (2009b) 特別支援学校学習指導要領解説

自立活動編 (幼稚部・小学部・中学部・高等部).

文部省（1999）盲学校, 竴学校及び養護学校学習指導 要領.

森㠃博志 (2002) 自閉症児におけるコミュニケーショ ン発達と臨床動作法. 治療教育学研究, 22, 41-48.

森㠃博志 (2003) 臨床動作法における身体相互交渉の 教育的意義. 東海・北陸心理リハビリテイション研 究会会報, 21, 1-9.

森㠃博志 (2004) 自閉的な子どもへの身体を介した関 わりの意義一発達的視点からの理論的考察一.リ八 
ビリテイション心理学研究, 32(2), 49-62.

本吉大介 (2014) 重度重複障がい者に対する臨床動作

法を通した関わりの意義一自立活動 6 区分の視点か

らの心理リハビリテイションキャンプにおける実践

の考察一. 大阪大谷大学教育研究, 39, 12-22.

成瀬悟策 (1995) 臨床動作学基礎. 学苑社.

大神英裕 (2002) 共同注意行動の発達的起源. 九州大
学心理学研究, 3, 29-39.

徳永 豊 (2004) 重度・重複障害児のコミュニケー ション行動における共同注意の実証的研究. 平成 11 年 14 年度科学研究費補助金成果報告書.

徳永 豊 (2009) 重度・重複障害児の対人相互交渉に おける共同注意. 慶應義塾大学出版会.

-2014.9.25 受稿，2015.6.27 受理一

Jpn. J. Spec. Educ., 53 (4), 285-295, 2015.

\title{
Practical Research
}

\section{Effects of Training for Independent Living (Jiritsu Katsudo): Children With Severe and Multiple Disabilities Including Breathing Disorders}

\author{
Kazuhiro OYAIZU* and Hiroshi MORISAKI** \\ * Toyota Special Needs School \\ (Toyota, 470-0342) \\ ** Aichi University of Education \\ (Kariya, 448-8542)
}

Jiritsu katsudo is a specialized subject area in the national curriculum for special schools that has the objective of training pupils with disabilities for independent living. The present study examined the effect of using the Dohsa-hou instruction method, which includes mental and physical relaxation, for the jiritsu katsudo instruction of 2 children with cerebral palsy and breathing disorders who were enrolled in a school for children with physical disabilities. After 1 year of this instruction, improvements were observed in the development of joint attention, blood oxygen saturation, posture depending on gravity, cognitive activity, and health. Experience suggests that Dohsa-hou may be useful for the jiritsu katsudo instruction of children with severe and multiple disabilities.

Key Words: independent living (jiritsu katsudo), Dohsa-hou, children with severe and multiple disabilities 